\title{
Influence of Nano-Barium Sulfate Agglomeration on Microstructure and Properties of the Hardened Cement-Based Materials
}

\author{
Mohamed El-Shahate Ismaiel Saraya1, Inas Mostafa Bakr² \\ ${ }^{1}$ Department of Chemistry, Faculty of Science, Al-Azhar University, Cairo, Egypt \\ ${ }^{2}$ Faculty of Engineering, Mattareya, Helwan University, Cairo, Egypt \\ Email: inasbakr@yahoo.com
}

Received 7 October 2015; accepted 21 November 2015; published 27 November 2015

Copyright (C) 2015 by authors and Scientific Research Publishing Inc.

This work is licensed under the Creative Commons Attribution International License (CC BY). http://creativecommons.org/licenses/by/4.0/

(c) (i) Open Access

\begin{abstract}
The aim of the present work is to study the effect of Nano-barium sulfate additions on the physicomechanical properties of hardened cement pastes. Nano-barium sulfate was prepared by the precipitation method. Eight mixes of filled cement pastes containing $0.5 \mathrm{wt} \%, 1.0 \mathrm{wt} \%, 1.5 \mathrm{wt} \%$ and $2.0 \mathrm{wt} \%$ of both nano-barium sulfate and micro-limestone were prepared and compared to the base OPC. The hydration characteristics were evaluated by the measure of combined water content, bulk density, total porosity and compressive strength for samples hydrated up to 90 days. The progress of hydration reactions was followed up by XRD analysis. The morphology and microstructure were studied by SEM. Nano-size barium sulfate acted as a nucleating agent and enhanced the hydration of cement pastes up to $2.0 \%$ mass content. Also, the microstructure was improved considerably. Accordingly, nano-size barium sulfate can be used successfully in the preparation of filled cement.
\end{abstract}

\section{Keywords}

Nano-Barium Sulfate, Cement Paste, Filler, Compressive Strength, Microstructure

\section{Introduction}

The use of active mineral admixtures such as condensed silica fume, coal fly ash, natural pozzolana, ground granulated blast furnace slag or fillers such as limestone or quartz, in concrete is an effective way of reducing

How to cite this paper: Saraya, M.E.I. and Bakr, I.M. (2015) Influence of Nano-Barium Sulfate Agglomeration on Microstructure and Properties of the Hardened Cement-Based Materials. Journal of Materials Science and Chemical Engineering, 3, 72-81. http://dx.doi.org/10.4236/msce.2015.311009 
the consumption of Portland cement clinker and then reducing the related $\mathrm{CO}_{2}$ emissions. The durability and mechanical properties of concrete are mainly dependent on the microstructure of the hardened cement paste and the interfacial transition zone through incorporating mineral admixtures [1] [2]. These mineral admixtures are believed to act through three roles [3]: 1) they tend to physically fill the void space between the larger particles, which is otherwise occupied by water that is not free to contribute to fluidity; 2) with time they react chemically with calcium hydroxide $(\mathrm{CH})$ to produce additional material such as pozzolanic C-S-H gels and 3) the pozzolanic C-S-H gels act as seeds to provide nucleation sites for cement hydration products.

Nanotechnology is being used in many applications and it has received increasing attention also in building materials, with potential advantages and drawbacks being underlined [4]. The nano-particles have attracted great interests due to their four major effects [5] [6], including size effect, quantum effect, surface effect and interface effect. The use of nanoparticles can not only change properties by prospect enhancing strength [7] and durability [8] but also by improving new functionality, such as photocatalytic (self-cleaning, pollution reduction and antimicrobial ability) [9], anti-fogging [10] and self-sensing capabilities [11]. Among the types of nanoparticles investigated are titanium dioxide $\left(\mathrm{TiO}_{2}\right)$ nanoparticles [12] [13], zinc dioxide $\left(\mathrm{ZnO}_{2}\right)$ nanoparticles [14] [15], calcium carbonate $\left(\mathrm{CaCO}_{3}\right)$ nanoparticles [16], nano- $\mathrm{Fe}_{2} \mathrm{O}_{3}$ [17] [18], $\mathrm{Al}_{2} \mathrm{O}_{3}$ nanoparticles [19]-[21] and nanoclays [22], although the majority of studies thus far have focused on nanosilica [23]-[26]. Previous researchers [27] [28] reported that functionalized multi-walled carbon nanotubes were found to improve strength properties of Portland cement.

Taking into account the available data concerning the effect of barium sulfate on cement characteristics along with its inertness in addition to the reported data about limestone filler in Portland cement, the present work aims at investigating the use of nano-size barium sulfate as a filler in Portland cement as compared to limestone filler.

\section{Experimental Work}

The starting materials were ordinary Portland cement (OPC), limestone of Samalout formation, from Beni-Khalid quarries, El-Minia, Egypt and nano-barium sulfate prepared by the precipitation method [29]. Their chemical analysis was conducted by a Philips X-ray fluorescence equipment model PW/1404 (Table 1). The limestone was ground to pass $90 \mu \mathrm{m}$ sieve. In order to investigate the effect of the nano-size barium sulfate on the physicomechanical properties of cement pastes, as compared to limestone, eight compositions were prepared in addition to the base OPC (Table 2). Each dry mix was homogenized in an automatic agate mortar for one hour.

Table 1. Chemical analysis of the starting materials, mass \%.

\begin{tabular}{cccccccccc}
\hline Oxide & $\mathrm{SiO}_{2}$ & $\mathrm{Al}_{2} \mathrm{O}_{3}$ & $\mathrm{Fe}_{2} \mathrm{O}_{3}$ & $\mathrm{CaO}$ & $\mathrm{MgO}$ & $\mathrm{SO}_{3}$ & $\mathrm{Na}_{2} \mathrm{O}$ & $\mathrm{BaO}$ & L.O.I \\
\hline $\begin{array}{c}\text { OPC } \\
\begin{array}{c}\text { Nano-size barium } \\
\text { sulfate }\end{array}\end{array}$ & 20.88 & 6.08 & 3.18 & 63 & 1.5 & 1.6 & 0.02 & 0.04 & 1.9 \\
$\begin{array}{c}\text { Limestone } \\
\text { Lime }\end{array}$ & 0 & 0 & 0 & 0 & 0 & 34.35 & 0 & 63.45 & 2.3 \\
\hline
\end{tabular}

Table 2. Compositions of the investigated mixes, mass \%.

\begin{tabular}{cccc}
\hline \multirow{2}{*}{ Mix } & \multicolumn{2}{c}{ Composition, mass \% } \\
\cline { 2 - 4 } & OPC & Nano-barium sulfate & Limestone \\
\hline NBS1 & 99.5 & 0.5 & 0.0 \\
NBS2 & 99.0 & 1.0 & 0.0 \\
NBS3 & 98.5 & 1.5 & 0.0 \\
NBS4 & 98.0 & 2.0 & 0.0 \\
LS1 & 99.5 & 0.0 & 0.5 \\
LS2 & 99.0 & 0.0 & 1.0 \\
LS3 & 98.5 & 0.0 & 1.5 \\
LS4 & 98.5 & 0.0 & 1.5 \\
\hline
\end{tabular}


Limestone filled samples were denoted in this work as LS1 up to LS4, while samples mixed with nano-barium sulfate were denoted as NBS1 up to NBS4. Dry mixes were molded into $2 \times 2 \times 2 \mathrm{~cm}$ cubes by the use of the required water of standard consistency [30]. The specimens were demolded after $24 \mathrm{~h}$, casting, and cured up to 90 days under tap water. Their bulk densities were determined according to Archimedes principle [31], while the compressive strength was measured according to ASTM designation: C109-80 [32]. The hydration was stopped by microwave drying technique [33]. Ignition loss test was conducted at $1000^{\circ} \mathrm{C}$ in order to determine the combined water content of dried samples. The microstructure was investigated via scanning electron microscope (SEM; JXA-840A electron probe microanalyzer, JEOL, Japan).

\section{Results and Discussion}

\subsection{XRD Results}

The reflection intensities of alite $\left(\mathrm{C}_{3} \mathrm{~S}\right)$ diminished greatly with the addition of nano-barium sulfate, while the amount of portlandite $(\mathrm{CH})$ that produced from hydration reaction increased (Figure 1). This indicated the good effect of nano-barium sulfate in the enhancement of hydration reactions. Barite reflections were detected in the filled samples and increased in accordance to the added amount of nano-barium sulfate, while the quartz content decreased as the amount of barium sulfate increased. The XRD results confirmed the complete inertness of nano-barium sulfate as no other phases were detected.

\subsection{Combined Water Content}

Figure 2 represented the combined water contents of the investigated mixes cured up to 90 days. Generally, the progress of curing time was accompanied by higher water contents due to the progress of the hydration of anhydrous clinker phases and the formation of hydration products [34]. Nano-barium sulfate filled cement pastes had the highest combined water contents as compared to OPC and limestone filled samples. Moreover, the increase of the nano-barium sulfate content resulted in higher combined water contents at all addition levels, while

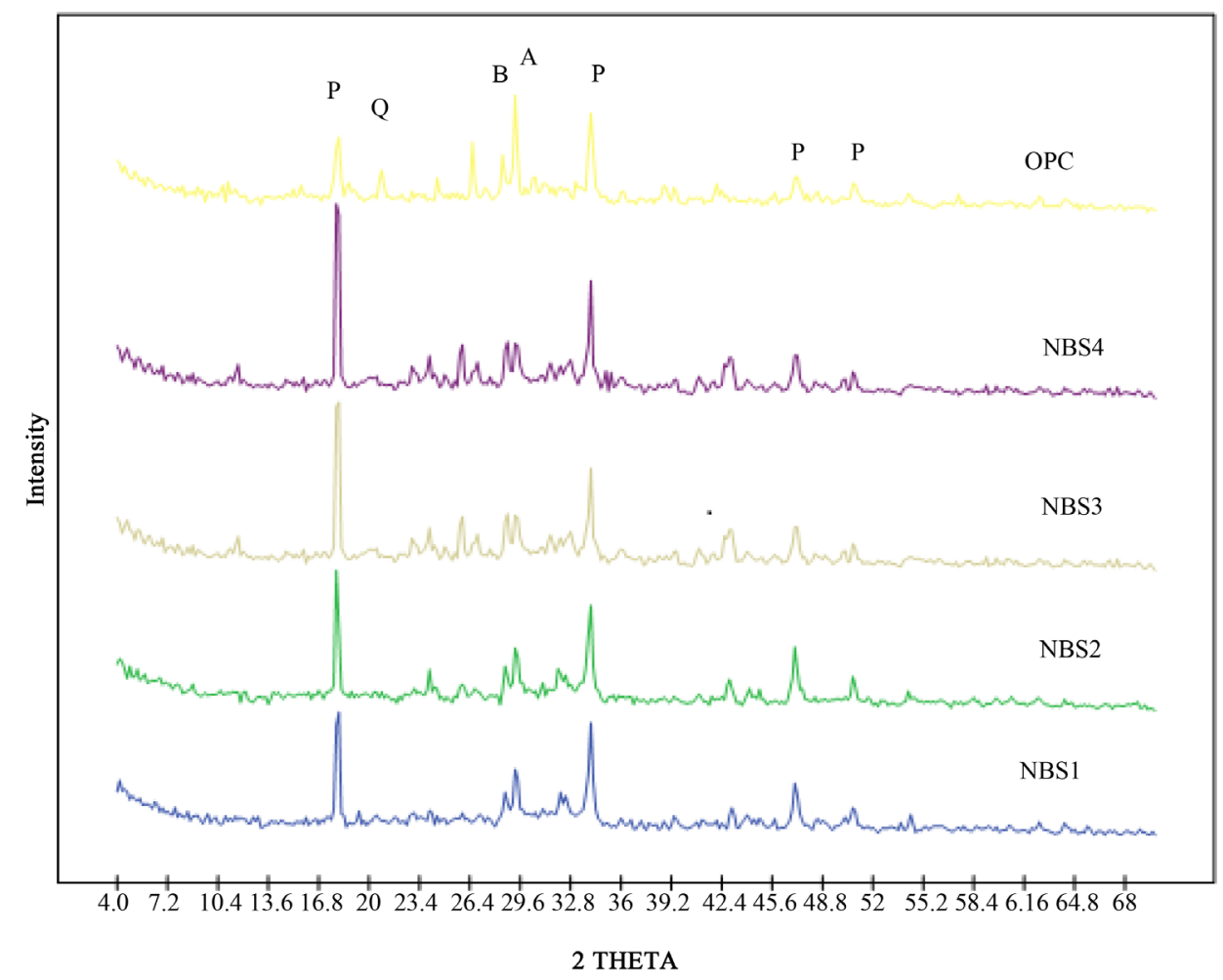

Figure 1. XRD patterns of samples hydrated up to 90 days $(\mathrm{P}=$ Portlandite, $\mathrm{A}=$ alite, $\mathrm{B}=$ Barite, $\mathrm{Q}=$ Quartz). 


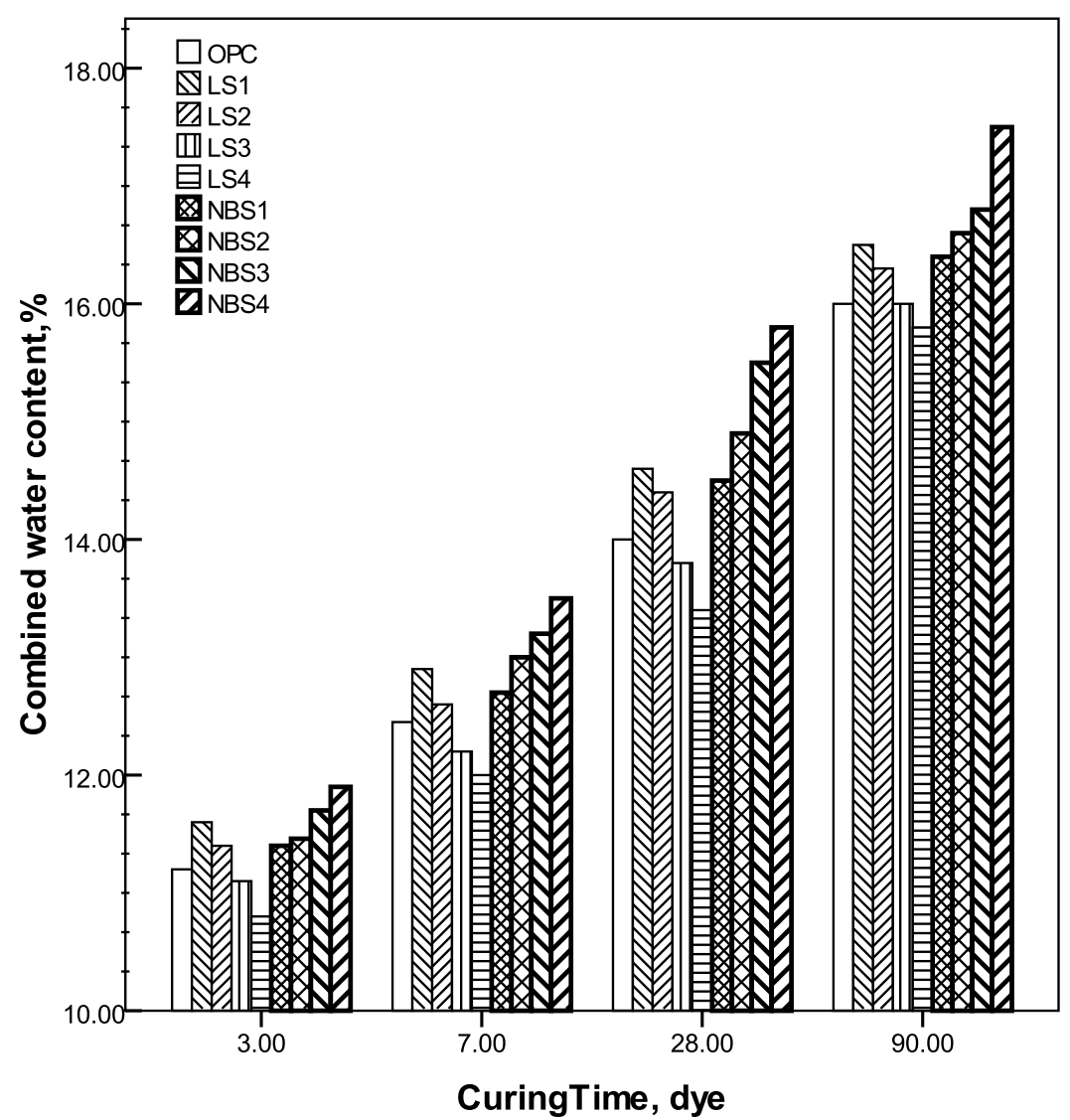

Figure 2. Chemically combined water content of the investigated mixes as a function of curing time.

high additions of limestone (LS3, LS4) resulted in lower combined water contents. This can be understood according to the dilution effect of filler that leads to less hydrated compounds. The continuous increase in combined water content for nano-barium sulfate blended samples is referred to the hydration enhancement, as given by XRD results, and the high fineness which helps in water absorption. These two factors seem to eliminate the dilution effect.

\subsection{Bulk Density and Total Porosity}

The bulk density increased while the total porosity decreased with the curing time for all hydrated cement pastes, (Figure 3 and Figure 4). As the hydration progressed, hydration products filled some of the pores and led to decrease the porosity and increase the bulk density of the hardened cement pastes. The bulk density values of nano-size barium sulfate filled cement pastes (up to 2\%) were higher than those of both OPC and micro limestone filled cement pastes at all ages of hydration. This is mainly due to the progress in the hydration process which is enhanced due to the high surface area of nano-barium sulfate in addition to its high specific gravity [35]. The bulk density of limestone filled cement samples were less than that of OPC and decreased gradually as the amount of limestone increased. Also, their porosities are generally higher than those of OPC at all curing times. On contrary to barium sulfate which is considered as a good stable filler and almost has no reaction with the hydration products, calcite present in limestone filler favors the formation of calcium carboaluminate hydrates with higher amount of water [36]-[39]. The porosity of the pastes typically increases with the water cement ratio. The water enclosed in the microstructure is directly responsible for the porosity of the hardened cement pastes [40].

\subsection{Compressive Strength}

The compressive strength increased with curing time for all cement pastes (Figure 5) due to the formation of 


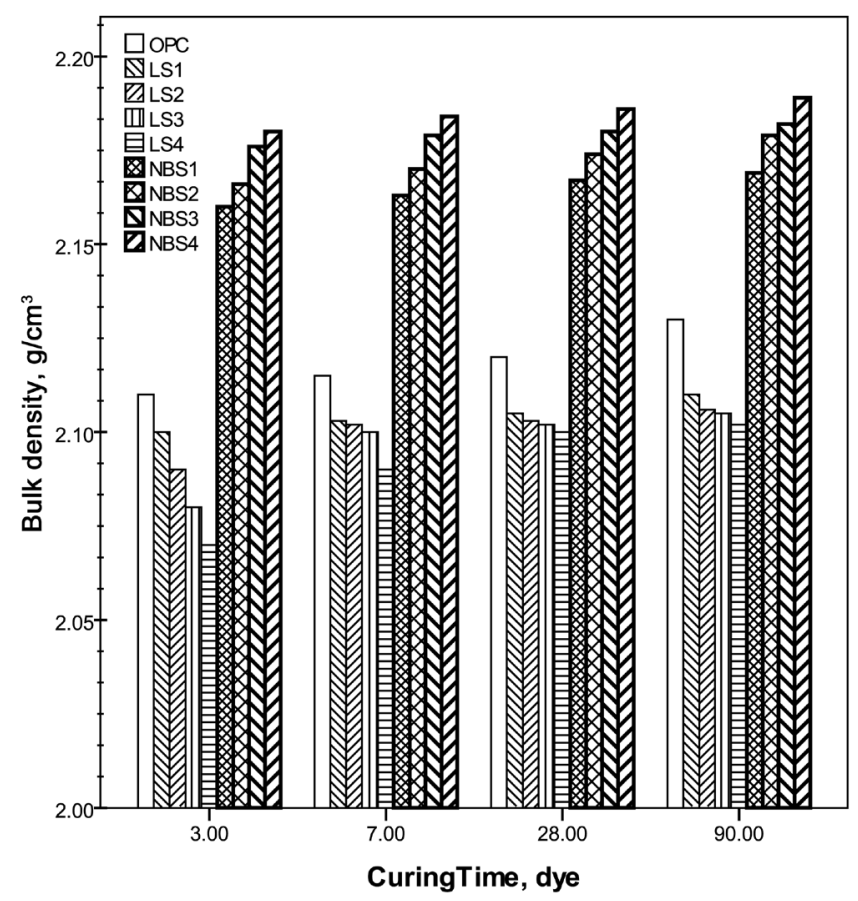

Figure 3. Bulk density of the investigated mixes as a function of curing time.

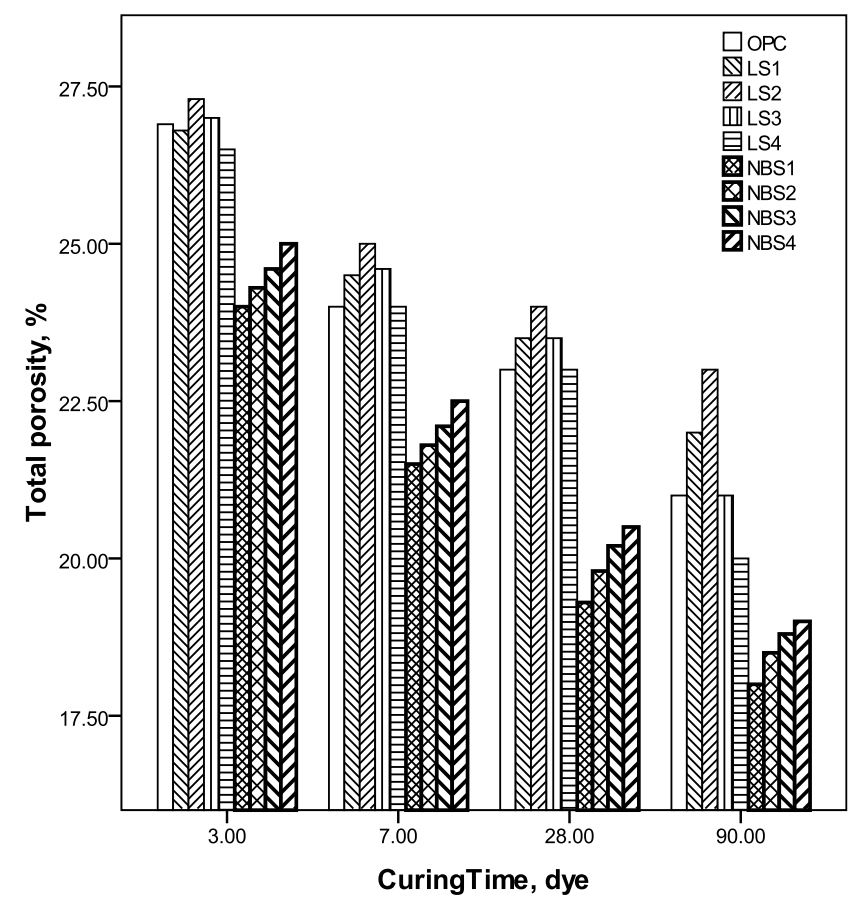

Figure 4. Total porosity of the investigated mixes as a function of curing time.

more cementing materials. Nano-barium sulfate cement pastes revealed higher compressive strength values than both OPC and micro limestone cement pastes. The high surface area of nano-barium sulfate activated the hydration of $\mathrm{C}_{3} \mathrm{~S}$ and favored the formation of additional amounts of CSH which is the main cementations material responsible for compressive strength gain. The porosity seemed to be the most intrinsic factor affecting the 
compressive strength. The highest strength values were observed for NBS1 samples which revealed the lowest porosities and its changes were compatible with porosity variations.

The strength activity index (SAI) was found [41] with Equation (1) below to determine the effect of the mineral additions on paste strength:

$$
\text { S.A.I. = Blended cement strength } / \text { Refrence cement strength }
$$

A coefficient greater than one therefore means that the mineral addition raised cement strength, while values of less than one denote lower strength in the blended cement than in the control. The SAI values for each age studied are plotted against the filler materials (Figure 6) At all ages, the pastes prepared with $0.5 \%, 1.0 \%, 1.5 \%$

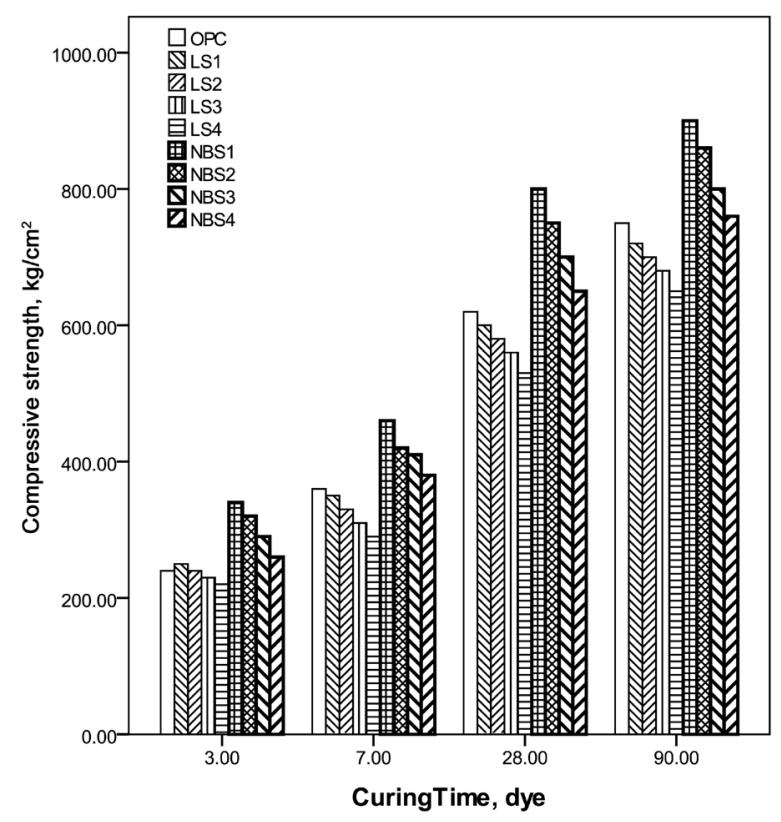

Figure 5. Compressive strength of the investigated batches as a function of curing time.

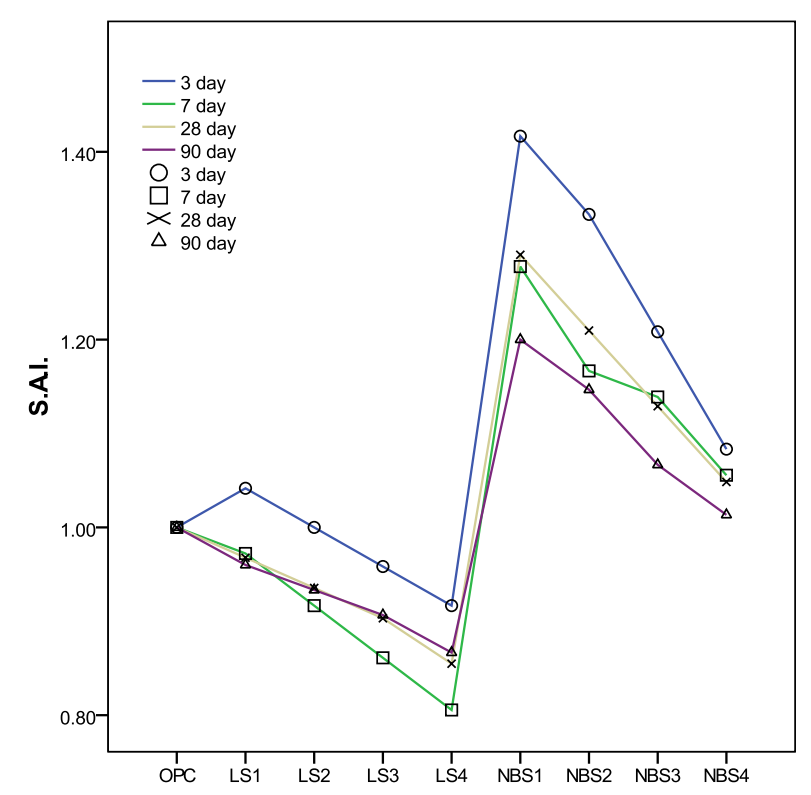

Figure 6. The strength activity index values for each age against the filler materials. 
and 2\% limestone exhibited lower strength than the OPC paste, except those of $0.5 \%$ limestone paste after 3 days exhibited higher strength has a result of acceleration effect of filler on cement hydration. On the other hand, the pastes with nano-barium sulfate content had SAIs of higher than one at all ages, an indication that the addition of barium sulfate had beneficial effect on strength of cement paste. This is mainly attributed to that the nano-barium sulfate acts as seeds to provide nucleation sites for hydration products and accelerate the rate of cement hydration. The highest strength value was achieved after 3 days, while the lowest value was observed after 90 days.

\subsection{Morphology and Microstructure}

The additions of nano-barium sulfate improved the microstructure considerably. The micrograph of the blank sample (OPC) indicated the formation of an opening pore system (Figure 7(a)). On the other hand, the additions of barium sulfate resulted in a dense structure and no macropores were observed (Figure 7(b) and Figure 7(c)). This can be understood according to packing effect of the nano particles as they filled the spaces inside the skeleton

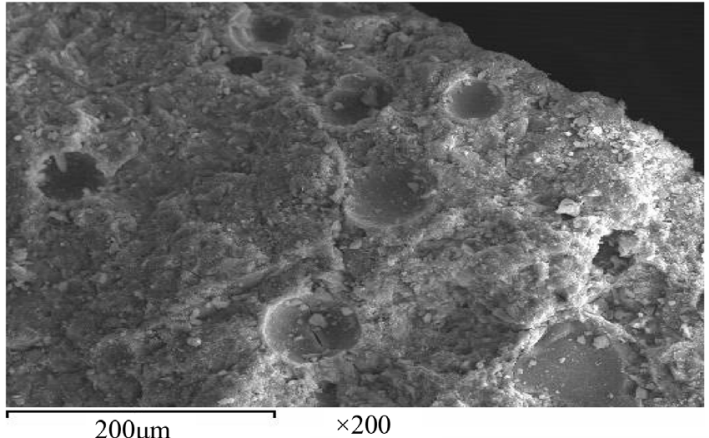

(a)

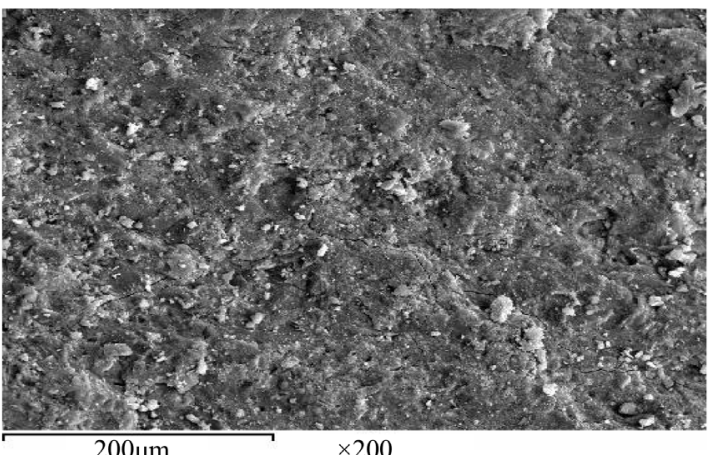

(c)

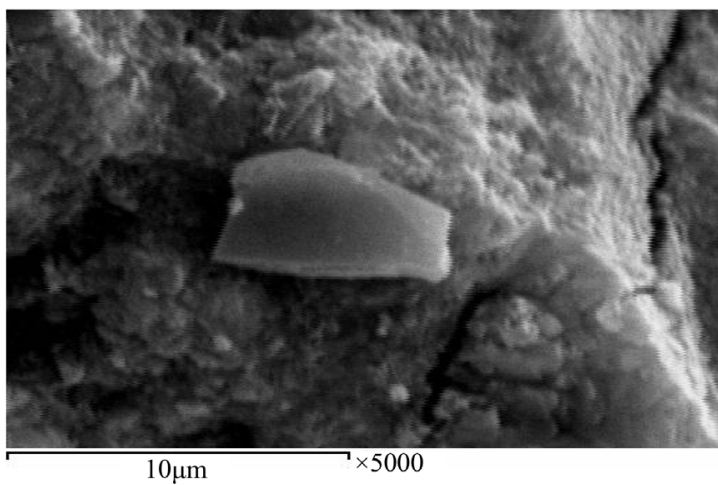

(e)

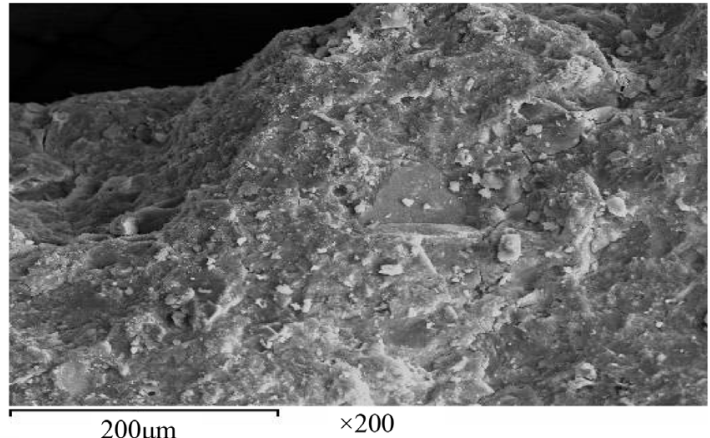

(b)

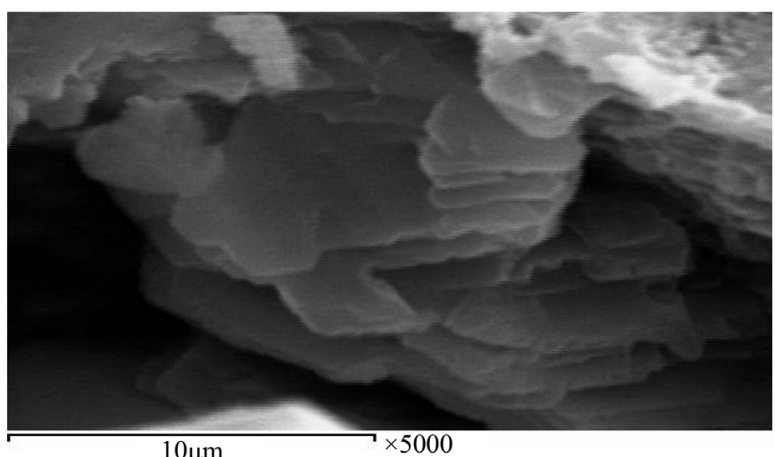

(d)

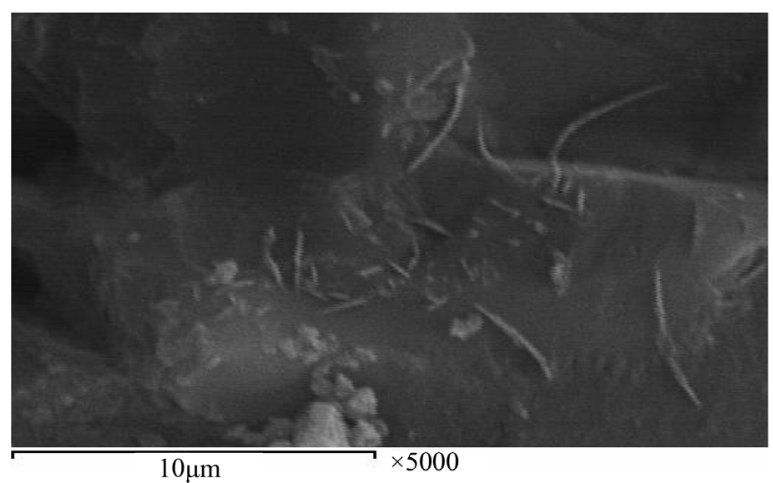

(f)

Figure 7. SEM micrographs of OPC, NBS1, and NBS2 Mixes hydrated up to 90 days. 
of the cement paste. Platelet-like hydrates of CSH were observed in OPC (Figure 7(d)), while the addition of $0.5 \%$ barium sulfate led to finer crystals (Figure $7(\mathrm{e})$ ). When $1 \%$ of barium sulfate was added, the structures became completely compact and smooth (Figure 7(f)).

\section{Conclusion}

The hydration reactions were enhanced by the addition of nano-barium sulfate. The combined water content of nano-barium sulfate filled cement increased progressively up to 2 mass \%, while the addition of limestone filler revealed a decrease of the combined water content at amounts higher than 1 mass \%. The bulk density, total porosity and compressive strength of nano-barium sulfate filled samples were improved remarkably as compared to both OPC and limestone filled samples at all filler contents. The compressive strength values of hardened cements were compatible with their porosity variations. The nano-barium sulfate filled cements were characterized by finer crystals, compact and smooth microstructure.

\section{References}

[1] Siddique, R. (2004) Performance Characteristics of High-Volume Class F Fly Ash Concrete. Cement and Concrete Research, 34, 487-493. http://dx.doi.org/10.1016/j.cemconres.2003.09.002

[2] Toutanji, H., Delatte, N., Aggoun, S., Duval, R.and Danson, A. (2004) Effect of Supplementary Cementitious Materials on the Compressive Strength and Durability of Short-Term Cured Concrete. Cement and Concrete Research, 34, 311-319. http://dx.doi.org/10.1016/j.cemconres.2003.08.017

[3] Lam, L., Wong, Y.L. and Poon, C.S. (2000) Degree of Hydration and Gel/Space Ratio of High-Volume Fly Ash/Cement Systems. Cement and Concrete Research, 30, 747-756. http://dx.doi.org/10.1016/S0008-8846(00)00213-1

[4] Pacheco-Torgal, F. and Jalali, S. (2011) Nanotechnology: Advantages and Drawbacks in the Field of Construction and Building Materials. Construction and Building Materials, 25, 582-590. http://dx.doi.org/10.1016/j.conbuildmat.2010.07.009

[5] Liu, X., Chen, L., Liu, A. and Wang, X. (2012) Effect of Nano-CaCO 3 on Properties of Cement Paste. Energy Procedia, 16, 991-996. http://dx.doi.org/10.1016/j.egypro.2012.01.158

[6] Wang, J.X. and Wang, L.J. (2004) Advances in the Applied Research of Nano-Material in Concrete. Concrete, 11, 1821.

[7] Sanchez, F. and Ince, C. (2009) Microstructure and Macroscopic Properties of Hybrid Carbon Nanofiber/Silica Fume Cement Composites. Composites Science and Technology, 69, 1310-1318. http://dx.doi.org/10.1016/j.compscitech.2009.03.006

[8] Konsta-Gdoutos, M.S., Metaxa, Z.S. and Shah, S.P. (2010) Highly Dispersed Carbon Nanotube Reinforced Cement Based Materials. Cement and Concrete Research, 40, 1052-1059. http://dx.doi.org/10.1016/j.cemconres.2010.02.015

[9] Lackhoff, M., Prieto, X., Nestle, N., Dehn, F. and Niessner, R. (2003) Photocatalytic Activity of Semiconductor-Modified Cement-Influence of Semiconductor Type and Cement Ageing. Applied Catalysis B: Environmental, 43, 205216. http://dx.doi.org/10.1016/S0926-3373(02)00303-X

[10] Diamanti, M.V., Ormellese, M. and Pedeferri, M. (2008) Characterization of Photocatalytic and Superhydrophilic Properties of Mortars Containing Titanium Dioxide. Cement and Concrete Research, 38, 1349-1353. http://dx.doi.org/10.1016/j.cemconres.2008.07.003

[11] Li, H., Xiao, H.G. and Ou, J.P. (2004) A Study on Mechanical and Pressure-Sensitive Properties of Cement Mortar with Nanophase Materials. Cement and Concrete Research, 34, 435-438. http://dx.doi.org/10.1016/j.cemconres.2003.08.025

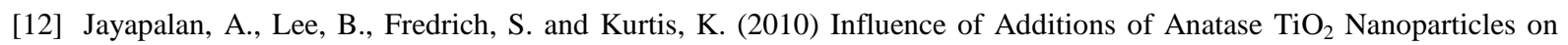
Early-Age Properties of Cement-Based Materials. Transportation Research Record: Journal of the Transportation Research Board, 2141, 41-46. http://dx.doi.org/10.3141/2141-08

[13] Chen, J., Kou, S.C. and Poon, C.S. (2012) Hydration and Properties of Nano-TiO 2 Blended Cement Composites. Cement and Concrete Composites, 34, 642-649. http://dx.doi.org/10.1016/j.cemconcomp.2012.02.009

[14] Nazari, A. and Riahi, S. (2011) The Effects of Zinc Dioxide Nanoparticles on Flexural Strength of Self-Compacting Concrete. Composites Part B: Engineering, 42, 167-175. http://dx.doi.org/10.1016/j.compositesb.2010.09.001

[15] Riahi, S. and Nazari, A. (2011) Physical, Mechanical and Thermal Properties of Concrete in Different Curing Media Containing $\mathrm{ZnO}_{2}$ Nanoparticles. Energy and Buildings, 43, 1977-1984. http://dx.doi.org/10.1016/j.enbuild.2011.04.009

[16] Sato, T. and Diallo, F. (2010) Seeding Effect of Nano-CaCO ${ }_{3}$ on the Hydration of Tricalcium Silicate. Transportation 
Research Record: Journal of the Transportation Research Board, 2141, 61-67. http://dx.doi.org/10.3141/2141-11

[17] Oltulu, M. and Şahin, R. (2013) Effect of Nano- $\mathrm{SiO}_{2}, \mathrm{Nano}-\mathrm{Al}_{2} \mathrm{O}_{3}$ and Nano- $\mathrm{Fe}_{2} \mathrm{O}_{3}$ Powders on Compressive Strengths and Capillary Water Absorption of Cement Mortar Containing Fly Ash: A Comparative Study. Energy and Buildings, 58, 292-301. http://dx.doi.org/10.1016/j.enbuild.2012.12.014

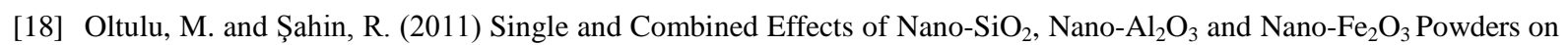
Compressive Strength and Capillary Permeability of Cement Mortar Containing Silica Fume. Materials Science and Engineering: A, 528, 7012-7019. http://dx.doi.org/10.1016/j.msea.2011.05.054

[19] Nazari, A., Riahi, S., Shamekhi, S.F. and Khademno, A. (2010) Influence of $\mathrm{Al}_{2} \mathrm{O}_{3}$ Nanoparticles on the Compressive Strength and Workability of Blended Concrete. Journal of American Science, 6, 6-9.

[20] Nazari, A. and Riahi, S. (2011) $\mathrm{Al}_{2} \mathrm{O}_{3}$ Nanoparticles in Concrete and Different Curing Media. Energy and Buildings, 43, 1480-1488. http://dx.doi.org/10.1016/j.enbuild.2011.02.018

[21] Nazari, A., Riahi, S., Riahi, S., Shamekhi, S.F. and Khademno, A. (2010) Mechanical Properties of Cement Mortar with $\mathrm{Al}_{2} \mathrm{O}_{3}$ Nanoparticles. Journal of American Science, 6, 94-97.

[22] Chang, T.P., Shih, J.Y., Yang, K.M. and Hsiao, T.C. (2007) Material Properties of Portland Cement Paste with NanoMontmorillonite. Journal of Materials Science, 42, 7478-7487. http://dx.doi.org/10.1007/s10853-006-1462-0

[23] Zahedi, M., Ramezanianpour, A.A. and Ramezanianpour, A.M. (2015) Evaluation of the Mechanical Properties and Durability of Cement Mortars Containing Nanosilica and Rice Husk Ash under Chloride Ion Penetration. Construction and Building Materials, 78, 354-361. http://dx.doi.org/10.1016/j.conbuildmat.2015.01.045

[24] Kong, D., Corr, D.J., Hou, P., Yang, Y. and Shah, S.P. (2015) Influence of Colloidal Silica Sol on Fresh Properties of Cement Paste as Compared to Nano-Silica Powder with Agglomerates in Micron-Scale. Cement and Concrete Composites, 63, 30-41. http://dx.doi.org/10.1016/j.cemconcomp.2015.08.002

[25] Hou, P.K., Kawashima, S., Wang, K.J., Corr, D.J., Qian, J.S. and Shah, S.P. (2013) Effects of Colloidal Nanosilica on Rheological and Mechanical Properties of Fly Ash-Cement Mortar. Cement and Concrete Composites, 35, 12-22. http://dx.doi.org/10.1016/j.cemconcomp.2012.08.027

[26] Hou, P., Cheng, X., Qian, J. and Shah, S.P. (2014) Effects and Mechanisms of Surface Treatment of Hardened Ce-

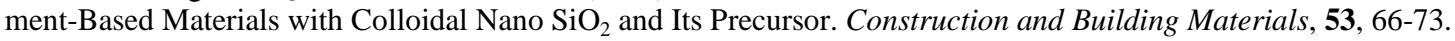
http://dx.doi.org/10.1016/j.conbuildmat.2013.11.062

[27] Chaipanich, A., Nochaiya, T., Wongkeo, W. and Torkittikul, P. (2010) Compressive Strength and Microstructure of Carbon Nanotubes_Fly Ash Cement Composites. Materials Science and Engineering: A, 527, 1063-1067. http://dx.doi.org/10.1016/j.msea.2009.09.039

[28] Konsta-Gdoutos, M.S., Metaxa, Z.S. and Shah, S.P. (2010) Multi-Scale Mechanical and Fracture Characteristics and Early-Age Strain Capacity of High Performance Carbon Nanotube/Cement Nanocomposites. Cement and Concrete Composites, 32, 110-115. http://dx.doi.org/10.1016/j.cemconcomp.2009.10.007

[29] Saraya, M.E.S.I. and Bakr, I.M. (2011) Synthesis of $\mathrm{Baso}_{4}$ Nanoparticles by Precipitation Method Using Polycarboxylate as a Modifier. American Journal of Nanotechnology, 2, 106-111. http://dx.doi.org/10.3844/ajnsp.2011.106.111

[30] ASTM Standards (1992) ASTM Designation: C187-92, Standard Test Methods for Normal Consistency of Hydraulic Cement.

[31] De’Gennaro, R., Cappelletti, P., Cerri, G., de’Gennaro, M., Dondi, M. and Langella, A. (2004) Zeolitic Tuffs as Raw Materials for Lightweight Aggregates. Applied Clay Science, 25, 71-81. http://dx.doi.org/10.1016/j.clay.2003.08.005

[32] ASTM Standards (1983) ASTM Designation: C 109-80 Standard Test Method for Compressive Strength of Hydraulic Cement Mortars.

[33] Saraya, M.E. (2010) Stopping of Cement Hydration by Various Methods. HBRC Journal, 6, 36-60.

[34] Salem, A.A.A. (2007) Utilization of Sugar Cane Bagasse Ash for Solidification/ Stabilization of Heavy Metals in Cement Pastes. Master's Thesis, Faculty of Science, Minia University, Minya.

[35] Tsuyuki, N., Watanabe, R., Koizumi, K., Umemura, Y. and Machinaga, O. (2000) Effects of Barium Salt on the Fixation of Chloride Ions in Hardened Mortars. Cement and Concrete Research, 30, 1435-1442. http://dx.doi.org/10.1016/S0008-8846(00)00308-2

[36] Hewlet, P.C. (1998) Lea’s Chemistry of Cement and Concrete. John Wily and Sons Inc., New York.

[37] Rahhal, V., Bonavetti, V., Trusilewicz, L., Pedrajas, C. and Talero, R. (2012) Role of the Filler on Portland Cement Hydration at Early Ages. Construction and Building Materials, 27, 82-90. http://dx.doi.org/10.1016/j.conbuildmat.2011.07.021

[38] Khan, M.I., Lynsdale, C.J. and Waldron, P. (2000) Porosity and Strength of PFA/SF/OPC Ternary Blended Paste. Cement and Concrete Research, 30, 1225-1229. http://dx.doi.org/10.1016/S0008-8846(00)00307-0 
[39] Garcés, P., Alcocel, E.G., Chinchón, S., Andreu, C.G. and Alcaide, J. (1997) Effect of Curing Temperature in Some Hydration Characteristics of Calcium Aluminate Cement Compared with Those of Portland Cement. Cement and Concrete Research, 27, 1343-1355. http://dx.doi.org/10.1016/S0008-8846(97)00136-1

[40] Stark, J. (2011) Recent Advances in the Field of Cement Hydration and Microstructure Analysis. Cement and Concrete Research, 41, 666-678. http://dx.doi.org/10.1016/j.cemconres.2011.03.028

[41] Burgos-Montes, O., Alonso, M.M. and Puertas, F. (2013) Viscosity and Water Demand of Limestone- and Fly AshBlended Cement Pastes in the Presence of Superplasticisers. Construction and Building Materials, 48, 417-423. http://dx.doi.org/10.1016/j.conbuildmat.2013.07.008 